\title{
EMERGENCE AND DEVELOPMENT OF WH-QUESTIONS IN JORDANIAN ARABIC-SPEAKING CHILDREN: A LONGITUDINAL STUDY
}

\author{
Jihad M. Hamdan \\ https://orcid.org/0000-0002-8952-6310 \\ Scopus Author ID: $\underline{10142472400}$ \\ jihaddan@yahoo.com \\ The University of Jordan, Jordan \\ Hady J. Hamdan \\ https://orcid.org/0000-0003-0146-511X \\ hady_hamdan@windowslive.com \\ The University of Jordan, Jordan
}

\section{Received November 1, 2020; Revised November 11, 2020; Accepted December 2, 2020}

\begin{abstract}
The main objective of this paper is to examine the emergence and development of wh-questions in two Jordanian Arabic-speaking pre-school children. Specifically, it investigates (1) how these children interact with wh-questions; which questions they find easier and thus earlier to acquire and why, and finally (2) what symptoms one can identify as characteristics of the intra-stage development of such questions. The data of the study are a subset of a large body of a longitudinal audio-taped corpus collected by the principal author, who happened to be a psycholinguist and the children's grandparent, on the basis of three-day, weekly sessions over a period of five years. The recordings were made in the family home environment during routine activities, mainly after dinner, and mostly in the presence of family members. The findings reveal the acquisition of wh-questions is a complex process that supports a general cognitive maturity model interpretation. The acquisition of wh-questions that ask about concrete objects/entities, that is mi:n 'who', we:n 'where' and Pe:f/fu: 'what' are produced and developed at an earlier stage than those questions which ask about abstract objects/entities, that is le:f ' $w h y$ ', ke:f 'how', gadde:f/kam 'how many/much' and wakte:f/Pe:mta 'when'. However, the subjects do not find the questions within each of the two sets equally easy/difficult. Put differently, in the first category, mi:n ranked first on the easy/difficult scale while ?e:f/fu: ranked third. Moreover, the order of acquisition in the second category suggested that it is easier for Jordanian Arabicspeaking children to ask about reason (le:f-why) than about time (wakte:f-when) and that to ask about quantity (gadde: f/kam-how many/much) is more difficult than to ask about manner (ke:fhow). The study argues that the emergence of wh-words does not mark but the onset of an accumulative process which includes a host of symptoms on the way to adult-like acquisition.
\end{abstract}

Keywords: acquisition, Arabic, longitudinal, wh-questions.

Гамдан Джихад, Гамдан Хаді. Поява й перебіг опанування спеціальних питань йорданськими арабомовними дітьми: лонгітюдне дослідження.

Анотація. Головна мета статті - вивчити виникнення та вікові особливості процесу опанування спеціальних питань двома йорданськими арабомовними дітьми дошкільного віку. Зокрема, автори досліджують (1) як ці діти взаємодіють зі спеціальними питаннями; які питання їм легше зрозуміти, а, отже, якими питаннями їм легше оволодіти i чому, i

(C) Hamdan, Jihad M., Hamdan, Hady J., 2020.

This is an Open Access article distributed under the terms and conditions of the Creative Commons Attribution 4.0 International Licence (https://creativecommons.org/licenses/by/4.0/).

East European Journal of Psycholinguistics, 7(2), 28-55. https://doi.org/10.29038/eejpl.2020.7.2.ham 
нарешті (2) які симптоми можна визначити як характеристики внутрішньоетапного розвитку таких питань. Дані цього дослідження є частиною великого корпусу аудіозаписів, зібраного першим співавтором, який $\epsilon$ психолінгвістом, а також дідусем дітей, на основі триденних щотижневих сеансів протягом п'ятирічного часу. Записи зроблені в родинному колі під час звичайних занять, переважно після обіду, і переважно у присутності членів родини. Результати дослідження засвідчили, що опанування спеціальних питань - це складний процес, який підтримує загальну інтерпретацію моделі когнітивної зрілості. Далі, висновки показують, що придбання спеціальних питань, що задають конкретні об'єкти / сутності, тобто mi:n 'xто', we:n 'de' та Pe:f/fu: 'щзо' представлені і розвинені у більш ранньому етапі, ніж ті питання, які задають про абстрактні об'єкти/сутності, тобто le:f 'чому', ke:f 'як', gadde:f/kam 'скільки' та wakte:f/Re:mta 'коли'. Однак випробувані не знаходять запитань у кожному з цих двох наборів однаково легкими / складними. Інакше кажучи, у першій категорії mi:n посідає перше місце за шкалою легких / складних, тоді як Pe:f//u: посідає третє місце. Більше того, порядок здобуття в другій категорії передбачав, що для йорданських арабомовних дітей легше запитувати про причину (le:f-чомy), ніж про час (wakte:-א-коли), а про кількість (gadde:f/kam-скільки) складніше, ніж запитати про спосіб (ke:f-як). Дослідження доводить, що поява спеціальних слів означає не ознаку, а початок накопичувального процесу, який включає безліч симптомів на шляху до оволодніння, подібного до дорослого.

Ключові слова: опанування, арабська мова, лонгітюдне дослідження, спеціальні питання.

\section{Introduction}

Asking and answering questions is an important feature of child language, particularly 3-6 year olds. Apparently, children use them as a discovery tool to learn about or to show knowledge of their immediate environment, including, objects, people and events. This paper reports on the findings of a qualitative longitudinal study on the acquisition of wh-questions by two Jordanian Arabicspeaking children. It traces the emergence and development of each question, showing the age of intra-development within each question exemplar as well as the age of inter-development from one question type to another. Thus, it does not highlight frequencies but focuses on the transitional qualitative changes and the age associated with the onset and progress of each along the acquisition path.

Arabic, in its various varieties, is spoken by approximately 300 million people; however, its acquisition, particularly by native speakers, has not been well researched. Though still limited in scope and number, the acquisition of phonology and morphology has attracted more research attention than other aspects of language (Abulhaija, 1989; Abdo \& Abdo, 1991; Amayreh \& Dyson, 1998; Ravid \& Farah, 1999; Hamdan \& Amayreh, 2007; Kalaldeh, 2018; Ghodayyah, 2019).

The acquisition of wh-questions in many languages, other than Arabic, has been the subject of many studies over the past three decades. It has been perceived as a complex process that involves a host of considerations, mainly linguistic and cognitive. On the linguistic level, the child cannot ask questions before acquiring the concepts underlying their answers, e. g., time, reason, quantity, etc. Nor can this be possible unless the question words needed for asking have already been encoded, rightly or wrongly, in one's lexicon. On the cognitive level, question words which may not appear significantly different in terms of concreteness/abstraction and lexical complexity (length and syllable structure) are 
more likely to be associated with varying complexity levels of cognition. Thus, it is quite reasonable to verify whether concrete concepts and question words associated with them are more likely to be acquired earlier and easier than abstract ones. Further, if the complete acquisition of wh-questions appears to be a complex process that extends over a number of years, can we identify a set of symptoms that characterize the intra-development of each wh-question?

Cairns \& Hsu (1978) indicated that subjects aged 3;0 to 5;6 years did not find wh-questions equally difficult. It was argued that the variable difficulty of the various forms of who questions "supports a parallel model of information retrieval and processing during discourse" (p. 477). In contrast, the variable difficulty of why and when questions was ascribed to progression in the children's ability to encode the concepts of causality and time linguistically. Further, the study reported that the subjects' interaction with how questions was found to be difficult because these questions "involve a number of unrelated skills" (p. 477).

Bloom, Markin and Wooten (1982) were not convinced that the acquisitional sequence of wh-questions in children is solely dependent on cognitive development. They argued that an integrative model of acquisition which hinges on both linguistic and nonlinguistic cognitive factors would provide a more feasible interpretation of this sequence.

Radford (1990) argued that English-speaking children comprehended subject questions before object questions. Further, he added that children sometimes misinterpreted object questions, e.g., who did you play with? as subject questions, and hence their answer $M e$. Stromswold (1995) suggested that this type of comprehension-based evidence needs further verification (p. 16). On examining the results of Cairns and Hsu (1978) and Ervin-Tripp (1970), among others, Stromswold (1995, p.16) posited that "previous acquisitional studies do not uniformly suggest that children acquire subject matrix questions before object questions".

Li, Tse, Wong, Wong \& Leung (2013) investigated the acquisition of interrogative forms and functions in Cantonese-speaking children beyond 3 years of age. Cantonese has six categories of questions. The first three are formed by adding simple interrogative words or rising intonation while the latter three involve the use of multiple question words, e.g. where and when ..., and more complex sentence structures. The researchers expected the latter three types to develop beyond age 3 (p. 170). The data were given by 492 Cantonese-speaking children belonging to three age groups $(3 ; 0,4 ; 0$ and $5 ; 0)$. All the six categories of interrogatives were produced by the three groups of children. Likewise, the children produced a total of 13 types of interrogative function that could classify into the three major categories: (1) information-seeking (request for information, RFI), (2) action-beseeching (request for action, RFA), and (3) non-information-seeking.

Specifically, the study reported here seeks answers to the following questions:

1. How do Jordanian Arabic-speaking pre-school children interact with whquestions? Which questions do they find easier and earlier to acquire? Why? 
2. What are the symptoms that characterize the intra-stage development of such questions?

\section{Method}

\section{Subjects}

Two normally developing male children named Jihad and Mohammad provided the data of the study. Jihad was born on 21 July 2002 and Mohammad on 19 October 2003. The children's nicknames, Juje and Ham will be used. In actuality, they were two siblings brought up in a middle class Ammani family whose native language is Jordanian Spoken Arabic (JSA). Further, it happened that Juje and Ham were the grandsons of the principal researcher and they lived with their parents and grandparents in the same family house. Two dialects, urban (by the children's mother) and rural (by all family members), were used at home; this explains why some sounds, particularly the velar voiced stop /g/ sometimes surfaced as a glottal stop / $/$ in their speech. The subjects were not exposed to any other language or regional Arabic variety before schooling, i.e., the age of 6 years when the data collection came to an end.

\section{Data collection}

The wh-question data of this study were a subset of a large body of longitudinal audio-taped corpus collected from the subjects by their grandparent, the principal author, who happened to be a psycholinguist on the basis of three-day, one-hour sessions per week over a period of five years. The recordings were made in the family home environment during routine activities, mainly after dinner, and mostly in the presence of family members.

For the purpose of this study, the whole set of data were carefully examined with a view to identifying all utterances that relate to subjects' actual production of, or response to wh-questions. This subset of data was extracted and saved in a separate file. The data were transcribed independently by the principal researcher and two research assistants with full observation and documentation of the date each wh-question was produced by each child. To examine transcription reliability, 20 percent of the sample was selected from the independently transcribed versions and examined against the audio-taped records. Most disagreements were resolved the first or second time the text was replayed. Transcription agreement between the three transcribers was 0.95 .3 percent. The parents' informed consent to allow the collection of data from their children was obtained before the onset of the research.

\subsection{Structure of wh-questions in Jordanian Spoken Arabic}

First, it is important to observe that Arabic wh-interrogative pronouns serve the same discourse functions conveyed by their relevant English wh-question words. In terms of syntactic position, they generally preface questions whose main purpose is to seek information that goes beyond 'yes' or 'no' responses on issues related to things (physical or abstract), time, place, reason, manner, possession, quantity, etc. JSA tends to put interrogative words first in wh-interrogative 
constructions. Although JSA allows for both VSO and SVO word order, it is believed that SVO is its more dominant and preferred order in declarative sentences among Jordanians, focus aside (Al-Momani and Al-Saidat, 2010). JSA which is spoken natively by around seven million speakers in Jordan is intelligible to a large number of speakers of Arabic, particularly in the Leavant, Egypt, Iraq, Yemen and the Gulf.

JSA has eight wh-forms, viz., two nominals (mi:n 'who/whom' and $2 e ; / l f u$ : 'what'), two adjectives (?aj 'which' and kam 'how many') and four adjuncts (we:n 'where' wakte:fl ?e:mta:) 'when', ke:f 'how' and le:f 'why'). Below are illustrative examples of JSA wh-questions words in these three main categories. All exemplars appear in clause-initial position, i.e. the neutral and canonical word order marked with a falling intonation contour. Three levels of presentation will be used if necessary; otherwise, transliteration and translation will be displayed.

\section{Nominal wh-words}

These words can fill both subject and object positions. Further, they generally ask about persons and things or objects. Each question is followed by its answer.

\section{Subject position}

(1) a. salim sa?al salma.

'Salim asked Salma.'

b. mi:n sa?al salma? salim.

'Who asked Salma?' 'Salim.'

(2) a. l-ba:b Pinfataћ.

the-door opened-passive

'The door opened.'

b. ?e:flfu: Pinfatah? l-ba:b

what opened-passive the-door

'What opened?' 'The door.'

Object position

(3) a. salim sa?al salma.

'Salim asked Salma.'

b. mi:n sa:lim sa?al? salma.

who(m) salim asked? salma

'Who(m) did Salim ask?' 'Salma.'

(4) a. salim fara kursi.

'Salim bought a chair.'

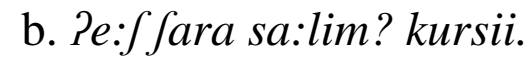

what bought salim? a chair

'What did Salim buy?' 'A chair.'

\section{Adjectival wh-words}

These include $? a j+\mathrm{N}$, e.g., ?aj findza:n 'which cup' and $\int u:+\mathrm{N}$, e.g. $\int u: l$ lo:n 'what colour'. 
(5) a. fare:t l-findza:n li-kbi:r.

I bought the-cup the-large

'I bought the large cup.'

b. Paj findza:n fare:t? li-kbi:r

Which cup you bought?' The large.

'Which cup did you buy/' 'The large one.'

(6) a. lo:n gami: $\underline{\text { si }}$ Pazrag.

colour shirt-my blue.

'The colour of my shirt is blue'.

b. fu: lo:n gami:sak? ?azrag.

what colour shirt-your? blue

'What colour is your shirt?' 'Blue.

\section{Adjunct wh-words}

These include we:n 'where' for place, wakte: (= Pe:mta) 'when' for time, le:f 'why' for reason and ke:f'how' for manner.

\section{Place adjunct}

There is only one place adjunct, namely, we: $n$ 'where'.

(7) a. mu:sa laga likta:b fi l-maktabi.

'Musa found the book in the library.'

b. we:n mu:sa laga likta:b? fi l-maktabi.

where musa found the-book? in the-library

'Where did Mousa find the book?' 'In the library.'

Time adjunct

The time adjunct in JSA is wakte: 'when' or its synonym Pe:mta.

(8)a. mu:sa firib il-ћali:b gabil fwajji.

mu:sa drank the-milk before a while

'Musa drank the milk a while ago.'

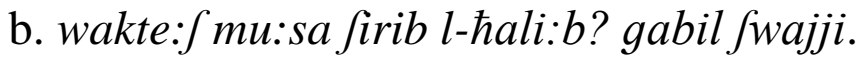

when musa drank the-milk? before a while

'When did Musa drink the milk?' 'A while ago.'

Reason adjunct

$l e: \int '$ 'why' is the only reason adjunct in JSA.

(9)a. sa:lim burgus la?innu mabsu:t.

salim dancing because he happy

'Salim is dancing because he is happy.'

b. le: sa:lim burgus? la? innu mabs $\underline{\text { u:t. }}$.

why salim dancing? because he happy

'Why is Salim dancing?' Because he is happy.'

Manner adjunct: ke:f 'how'

(10) a. sa:lim Padza ho:n bi-ssajja:ra.

salim came here by-the car 
'Salim came here by car.'

b. ke:f sa:lim ?adza ho:n? bi-ssajja:ra.

how salim came here? by-the car

'How did Salim come here?' 'By car.'

\section{Results and Discussion}

As the study is based on two subsets of wh-question data, the first elicited from Juje and the second from Ham, the results pertinent to each subset will be presented and discussed separately before a systematic comparison between the two subsets is provided. The age at which the subject was able to comprehend a particular wh-question before actual production will be reported but the acquisition focus will be placed on the age at which each question form was actually produced. In this context, it is useful to observe that the complete acquisition of each form tends to undergo a number of sub-stages as will be shown in the course of presentation and discussion. Put another way, the emergence of the question or its first occurrence marks the onset of acquisition only. In light of this, a set of symptoms that characterize that characterize the intra-stage development of such questions will be suggested.

\section{Juje's path of acquisition}

The analyzed data consisted of 2219 wh-questions which were collected from age 1;4,3 to 6;0. Below is a brief account of Juje's acquisition path of wh-questions.

\section{The acquisition of mi:n 'who' and lami:n 'whose'}

The first wh-question attested in Juje's data was mi:n 'who'. It appeared in subject position as a one-word question at the age of 1:8, 2 when he responded to a knock on the main door of their flat by his grandmother who was visiting them. In fact, mi:n was mispronounced as ni:m providing an earlier example of metathesis. In this context, adults tend to use mi:n as a single word question or as part of a short question, i.e. mi:n 'a lba:b? 'who's knocking at the door?' At this age, Juje was also able to answer mi:n questions that are not specifically used to identify door knockers.

(11) Grandpa: mi:n maffatlak? 'Who combed your hair?'

Juje: ha:di 'Hady'.

At 2;1.3, Juje was able to answer prepositional mi:n questions, i.e. $m a^{c}$ mi:n 'with whom' as in:

(12) Mom: $m a^{c}$ mi:n kunt barra? 'With whom were you outside?'

Juje: si:du 'Grandpa'.

On examining all Juje's mi:n questions, none of the question words was found to be in the object position; actually all functioned as subject. However, the question constructions varied from verbless sentences to constructions with intransitive and transitive verbs as in: 
(13) Juje: mi:n maratak si:du 'Who's your wife, grandpa?' [Verbless at 2;9,20] Grandpa: Pilli ga: ${ }^{c} d i$ 'The one who is sitting'.

Juje: la? Pilli najmi 'No, the one who is sleeping'.

(14) Juje: mi:n tabbil 'Who's knocking?' [Intransitive at 2;2,15]

Mom: si:du 'Grandpa'.

(15) Juje: mi:n tafa iddaw 'Who turned off the light?' [Transitive at 2;9,11]

Grandpa: ?ana. Pid wi: 'It's me. Turn it on'.

Juje: dawe:țu. xalli:ni ?al' $a b$ 'I turned it on. Let me play'.

The absence of object mi:n questions may be ascribed to the more complexity of this construction compared with their subject counterparts. The object form, unlike the subject mi:n, requires, inter alia, the obligatory use of the relative pronoun Pilli 'that' and the retention of reflexive relative pronoun as in (15).

(16) mi:n (?illi) fa:f salma? sa:lim. [Subject]

who that saw salma? Sa:lim.

'Who is the one who saw Salma?' 'Salim'.

(17) mi:n Pilli fa:fha sa:lim? salma. [Object]

who that saw-her salim? salma.

'Who is the one that Salim saw?' 'Salma'.

At 2;4,25, Juje produced the prepositional question lami:n, literally 'to whom' which is equivalent to 'whose' in English as in:

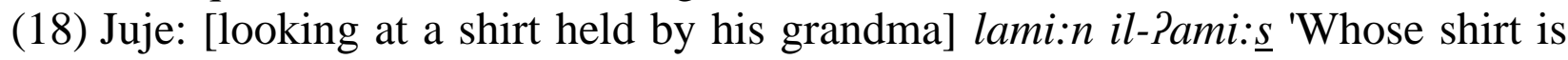
this?'

Grandma: la ha:di 'Hady's'.

It is worth noting that lami:n in this sense can be viewed as a separate whword that indicates possession. An important feature of this question word is that it is always followed by a definitive noun, e.g., a noun preceded by the definite article ?il 'the' as in lami:n Pil-galam 'whose pen is this?' Further, it is different from the literal combination of the preposition la 'to' and mi:n 'who' which exemplifies piedpiping as in lami:n dzibit likta:b 'To whom did you bring the book?' A possible answer to this question is la sa:lim 'to Salim'.

The acquisition of we:n 'where'

Juje showed comprehension that we:n 'where' questions ask about place or location. It appeared that the earliest forms of we:n questions Juje was introduced to were in the context of his mom's testing his knowledge of body parts, belongings and close family members. The analysis of data revealed that at the age of $1 ; 4,14$, Juje was able to respond correctly to such questions, by pointing, touching, etc., as in:

(19) we:n ða:nak/ lucibtak/ ma:ma? 'Where's your ear/toy/mom?'

Body parts included, inter alia, ear, nose, mouth, hair, teeth, hand, finger, head, back and leg. Belongings and objects in the immediate environment included 
socks, shirt, trousers, pillow, bed and toy car. Family members included dad, mom, brother and grandparents.

The data showed that Juje was able to produce and respond correctly to other we:n questions when he was around 1;10 as in:

(20) Juje: we:n ba:ba? 'Where's dad?'

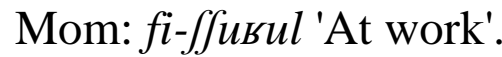

Mom: tajjib Pinta we:n kunit? 'Ok! Where were you?

Juje: balla [for barra] 'Outside'.

Sometimes, his answer was a whole sentence:

(21) Grandpa: we:n il-galam? 'Where is the pen?'

Juje: zatte:tu bawwa [for barra] 'I threw it outside.' [1;11,26]

Further, Juje was able to answer we:n questions which included a specific time reference:

(22) Grandpa: we:n biddak tru: $\hbar$ bukra? 'Where do you want to go tomorrow?'

Juje: jawa 'To Yara'. [1;11,26]

At a later stage, at the age of $2 ; 3,6$, he was able to answer prepositional we:n questions as in:

(23) Mom: mi we:n bi:dzi iffita 'Where does rain come from?'

Juje: sama 'Sky'. [Note the absence of the preposition min 'from' as Juje was in the telegraphic stage].

While the structural complexity of wh-question constructions tends to increase over time, a simple construction, sometimes the wh-word alone or combined with a noun or a pronoun, may also occur rather late on the path of acquisition as in:

(24) Juje (to grandpa while watching a man shooting with a gun on TV): Pinta 'indak baru:di 'Do you have a gun?' $[3 ; 8,13]$

Grandpa: ?a: 'Yes'

Juje: we:nha 'Where is it?'

Grandpa: biddi:: Pagullak 'I don't want to tell you'.

Here, the wh-question is part of a rich context which started with a yes/no question by the child. The wh-question unfolded as a follow up, and thus the simple and short construction.

Juje was also able to use we:n in indirect questions, a sign of developing an adult-like understanding and use of the function of this question word whether to ask for information or report it.

(25) Juje (to grandpa): haj Palam Paћki:lak we:n la?e:tu 'Here's a pen. Shall I tell you where I found it?' [4;9,23] 
Grandpa: ?a: 'Yes'.

Although Jordanian children are not formally introduced to Modern Standard Arabic (MSA) before schooling, Juje was able to perceive that we:n and its MSA ?ajna are free variants that ask about place.

(26) Juje: Pajna ?anta muxtafi ja: si:du 'Where are you hiding, grandpa?' [4;10]

Grandpa: fil- hadi:qa 'In the garden'. [Answer in MSA]

Juje's ability to use dialectal and standard forms may be taken as an indication of mastery of this question form.

The acquisition of ?e:flfu: 'what'

In JSA, Pe:f 'what' has another dialectal variant, viz., $\int u$ : Juje was able to answer ?e:f/fu: questions in object position where the answer refers to a thing/object around 1;6 as in:

(27) Grandpa: ?e: ? Rakalit? 'What did you eat?'

Juje: $\underline{t} a: \underline{t} a$. 'Potato'.

At 2;0,20, he was able to report actions in response to $f u$ : questions as in:

(28) Grandpa: fu: bisawwi il-walad? 'What's the boy doing?'

Juje: ?ukkud. 'Running.'

Mom: Ju: bitsawwi? 'What are you doing?'

Juje: bamsaћ_itta:wli. 'Cleaning the table'.

The first production of $2 e: \int$ attested in the data was at the age of $2 ; 2$ when he was stunned by a loud sound on television.

(29) Juje: Pe:: Pisso:t? 'What's this sound?'

Grandpa: min il- dziha:z. 'From the device'.

Around three months later, Juje started to use ?e: $\int$ with colour terms while his uncle was fixing the gas bottle.

(30) Juje: ?e: lo:nha [the bottle]? 'What colour is it?' [2;6,21]

Uncle: ?azrag. 'Blue'.

Shortly afterward, Juje used $2 e: \int$ or $\int u$ : to convey pragmatic functions other than mere asking for information, e.g. to show unease with something, seek clarifications a multi-purpose question, whether the focus is an object, colour, smell, clarification, protest, service, comment, etc.

(31) Juje (showing unease with a bad smell): fu: ri:ћa? 'What's this bad smell?' $[2 ; 8,4]$

Grandpa: sama:d. 'Fertilizer'.

(32) [Juje's father was saying something which Juje didn't understand and thus asked for clarification].

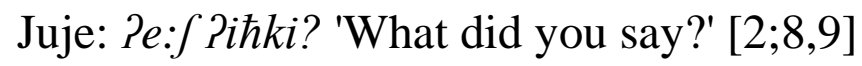


Dad: halla bagullak. 'I'll tell you right now'.

(33) Mom: bala: $t_{i l}^{c}$ ab fi-ttra:b. 'Stop playing with soil'.

Juje (protesting): $\int u$ : daxlik Pinti? 'What have you to do with this?' [This $f u$ : is similar to le:f. Compare: le: btiddaxli? 'Why are you interfering?'] [3;0,27]

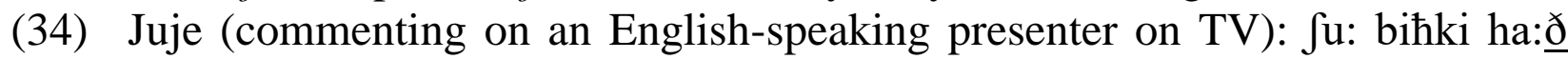
Pizzalami? 'What language does this man speak?' $[4 ; 2,13]$

Grandpa: Pingli:zi. 'English'.

Juje also used $\int u$ : as part of a monologue/fake dialogue in which he imagined himself conversing with Mom who was about to go shopping.

(35) Juje impersonating Mom (as if offering a service)

Mpm: fu: ?adzi:blak mac $i$ dzu:dzu? 'What do you want me to bring you Juje?'

Juje: 'ilki. 'Gum'. [3;5,19]

Signs of complete mastery of Pe:flfu: questions might have shown up in Juje's use of the idiomatic expression $\int u$ : ra:jak 'what about', after turning five, to make suggestions or seek approval as in:

(36) Juje: fu: ra:jak ja Ham nil'ab ha:ji illucbi? 'What about playing this game Ham?' [5;2]

Ham: $e: \int^{\prime}$ What?'

Juje: niftaћ_ridzle:na he:k winћarrikhum. 'Open our legs this way and move them'.

Ham: ma:fi. 'Okay'.

The acquisition of le: $\int$ 'why'

The first adjunct le: $\int$ 'why' question was attested in Juje's data at the age of $2 ; 4,10$ when he saw his uncle Wael upset and sitting alone. Juje commented on his uncle's status then asked about the reason.

(37) Juje: wa:Pil zacla:n. le:厅 zacla:n? 'Wael is upset'. 'Why are you upset?'

Wael: $r u: \hbar$ fik $^{c}$ anni 'Leave me and go away'.

Another le:f question using the same adjective $z a^{c} l a: n$ 'upset' appeared a month later.

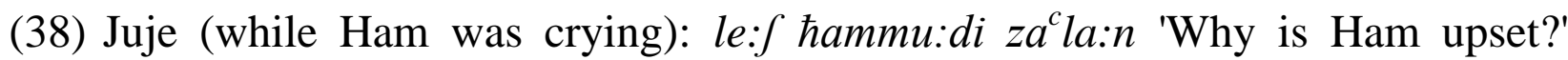
$[2 ; 5,17]$

Grandpa: ?is?alu. 'Ask him'.

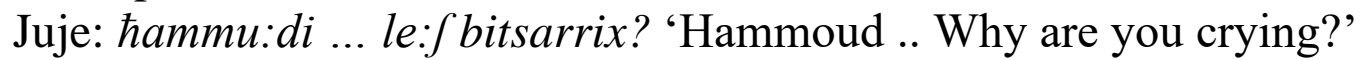

Ham: mif Juslak. 'None of your business.'

A third transitional le: $\int$ question attested in Juje's data was around the age of $2 ; 6,10$ when his uncle threw away Juje's toy. It seems that his uncle's behaviour was a reaction to Juje's noisy play around as revealed in the following exchanges: 
(39) Uncle: xalas $d_{3 u}$ :dzu. bikaffi licib. 'Juje! Stop playing. Enough is enough' (and he threw away Juje's toy truck).

Juje (in an angry tone): 'le: $\int z i t t u$ ' 'Why did you throw it away?'

Uncle: he:k. 'Just like that'.

Juje: (burst into crying)

Apparently, the main function of Juje's question was to protest against his uncle's act rather than to seek its reason.

A further example was attested in another context at the age of 2;7. His mother was dressed and about to leave. He was watching, then he asked her a we:n question whose answer invited a le:f question.

(40) Juje: we:n biddik tru:ћi? 'Where are you going?'

Mom: ' ${ }^{c}$-lbank. 'To the bank'.

Juje: le:f'Why?'

Mom: ' a Ja:n Padzi:b masa:ri. 'To get money'.

It seems that Juje at that point in time knew the word bank but he did not probably know why his mother wanted to go there.

In another context, at the age of 2;7, 10, Juje asked a le: $\int$ question and suggested an answer in a follow up yes/no question.

(41) Juje (watching his grandpa putting on his jacket): le:f la:bis dzake:t? la Pinnak barda:n? 'Why are you wearing a jacket? Feeling cold?'

Grandpa: mazbu:t. 'Yes.'

It seems that Juje was not looking for a genuine reason but trying to confirm a hypothesis.

Although the timeframe of a large number of le:f questions was the present moment, Juje sometimes asked about events with a past time reference as in:

(42) Juje (to grandpa): zama:n Pinta macallamtif ha:di ya si:du. 'It has been a long time since you taught Hady'.

Grandpa: $\underline{s} a \hbar i: \underline{h}$. 'Right'.

Juje: le:f? 'Why?' [3;7, 11]

Grandpa: matalabif minni. bas jutlub. 'He has not approached me. I'll do if he asks'.

As is clear, Juje recalled a past event that had not been repeated for a long time and asked about the reason.

Mostly after turning five, Juje used le:f to preface embedded clauses in indirect questions. When faced with a follow up le: $\int$ question by his mom, Juje provided information that showed his full understanding of the main function of this question type, i.e. to give reason. 


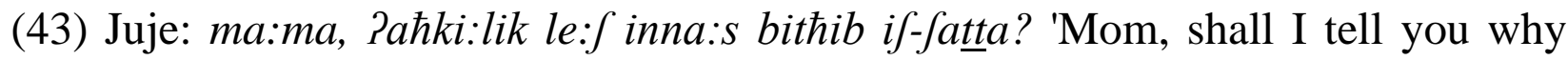
people like minced pepper?' [5;6]

Mom: le:f? 'Why?'

Juje: la Pinha btuktil il-jaraOi:m 'Because it kills germs'.

Before closing, one may wish to observe that Juje did not always accept the given answers; in effect, he sometimes showed his unease with some answers.

(44) Juje: le: $\int^{c} a m m u$ ha:di ma: bila: ${ }^{c} i b n a ?$ ? 'Why doesn't uncle Hady play with us?' [5;7]

Grandpa: tfa:ham mac $a$ : . 'Talk to him'.

Juje: ' ammu ha:di ma: bicrif ittafa:hum. 'Uncle Hady doesn't leave room for this'.

The acquisition of ke:f'how'

The first ke:f 'how' question which Juje showed understanding of and was able to respond to verbally was the ritualized and routine question ke:f $\hbar a: l a k$ 'how are you' as in:

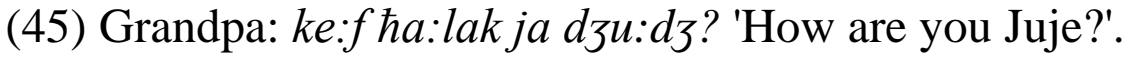

Juje: ћamdulla. 'Thanks to Allah'. [1;11]

At 2;3 Juje was able to engage in short exchanges beyond the ritualized ke:f. The example below included both we: $n$ and $k e: f$.

(46) Grandpa: we:n ruhit Pinta w ba:ba? 'Where did you go with your dad?'

Juje: ' $a$-ssu:g. 'To the market'.

Grandpa: ke:f ka:n il-mifwa:r? 'How was the trip'.

Juje: munta:z. 'Excellent'.

The first ke:f question Juje produced was when he was nearing three [2;9,22] and it consisted of the wh-word only. Juje at the time was sharpening a pencil but with obvious difficulty.

(47) Grandpa: xalli:ni ?asa: 'dak 'Let me help you'.

Juje: $k e: f$ 'How?'

Grandpa: ha:t ?awardzi:k 'Look! I'll show you'.

Shortly after that, Juje used ke:f in a complete sentence while he and his grandpa were picking figs in the garden.

(48) Juje: ke:f biddi Pagattic ti:n? 'How can I pick figs?' [3;1]

Grandpa: halla baћimlak ${ }^{c} a f a: n$ ittu:l. 'Now I'll carry you up to reach the figs'.

Even more interesting is Juje's use of ke:f in fake dialogues imagining himself conversing with the bathroom as well as with his mother, a clear indication that ke:f questions became a vibrant component of his semantico-syntactic repertoire. 
(49) Juje [talking to the bathroom]: ke:fak ja ћamma:m? ifta?t illak. biddi ?armi:k fil-ћa:wji. 'How are you bathroom? I missed you. I want to throw you into the garbage container'. [3;3, 4]

(50) [Part of a fake/imaginative dialogue with his mom]

Juje: ke:f ha:lik? 'How are you?' [3;5,19]

Mom: (taking her turn) kwajsi. 'Fine'.

Juje was also able to use $k e: f$ as a direct object clause, another indication of his understanding that $k e: f$ expresses manner.

(51) Juje: bas ?akbar limcalmi bit dlimni ke:f ?aktub. 'When I grow up the teacher will teach me how to write'. $[3 ; 4,26]$

\subsection{The acquisition of gadde: $/ /$ kam 'how many/how much'}

When Juje was exposed to a gadde:5 'how many' question at the age of 2;6,7, he answered using the plural noun of the thing he was asked about (e.g. fingers) but he did not specify number.

(52) Grandpa: (spreading his right hand before Juje) Pittalla ha:n. gadde:f haðo:l [?as $a: b i^{c}$ 'fingers]? 'Look here. How many are these?'

Juje: ?as $a: b i{ }^{c}$. 'Fingers'.

Either Juje did not perceive that gadde: $\int$ here requires quantity or he confused it with ?e:f 'what', which requires mere nomination of substance/things. The confusion may be due to phonic prominence as both words have the same ending $e: \int$.

Almost a year later, Juje's grandpa asked him to count and the latter counted from 1 to 5. [route memory], then he showed up two fingers to Juje and asked:

(53) Grandpa: gadde: h haðo:l? 'How many are these?'

Juje: wa:had 'One'. [3;5]

Grandpa: la? Pintabih kwajjis. 'No, look carefully'.

Juje; kta:r. 'Too many'.

Grandpa repeated the gadde: $\int$ question with his three fingers up but received the same answer. This may explain why gadde: $\int$ is acquired rather late. Below is the first accurate use of gadde:f by Juje while communicating with Ham and grandpa. He was 3;8, 26.

(54) Juje: $\hbar a m$ ! Pittalla ${ }^{c}$ gadde: $\int^{c}$ indi sajjara:t. kti:r. 'Ham! Look how many cars I have. Too many'.

Juje: (to his grandpa): fuftillak sajjara ze:ti. 'I found you a dark green car'.

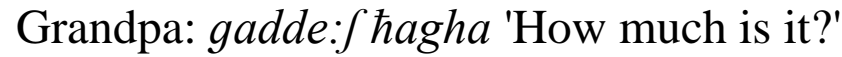

Juje: ma: $b a^{c}$ rif. il-bajja ${ }^{c} b^{c}$ rif gadde: ${ }^{2}$ hagha. 'I don't know. The seller knows how much it is'.

On the second day, the following question was produced.

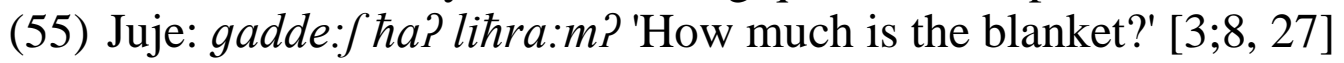

Ham: sitti 'Six'. 
The acquisition of wakte://Re:mta 'when'

Juje was able to show understanding of the concept of time when he was around two years. From a cognitive perspective, it is believed that such understanding is a prerequisite for initiating adjunct time questions. The following example illustrates Juje's correct use of time reference, Pimba:riћ 'yesterday', when his mother offered him kna:fi 'type of sweet'.

(56) Mom: biddak kna:fi? 'Do you want kna:fi?' [2;3,24]

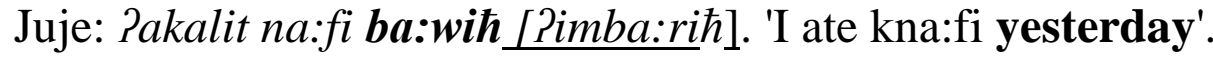

At 2;4,2, Juje responded to a time question prefaced with wakte: 'when' asked by his grandpa. He used a time reference in the answer, an indication of his awareness that wakte: $\int$ asks about time, though the answer is not fully accurate. In the family both wakte: and Pe:mta were used interchangeably.

(57) Grandpa: wakte:S ruhit ${ }^{c} a-t t a: d 3$ ? 'When did you go to Taj?'

Juje: jo:m 'Today'. [In fact, it was a few days ago.]

The first occurrence of wakte: $\int$ questions attested in the data was at the age of $4 ; 6$.

(58) Juje: si:du zama:m ma Pidzi:t 'inna. wakte:f biddak ti:dzi? 'Grndpa, you haven't visited us for a while. When will you be coming?'

Grandpa: mif ${ }^{c}$ arif. jimkin bukra.'I don't know. Maybe tomorrow'.

Apparently, if no earlier examples were produced by the subject but missed by the data collector, then wakte: $\int$ was probably the last question word Juje had acquired.

The acquisition of ?aj/Panu: 'which'

The question word $P a j$ can be followed by both masculine and feminine nouns, e.g. ?aj walad/binit? 'which boy/girl?' In contrast, ?anu: is followed by masculine nouns only, e.g. ?anu: walad? 'which boy?' while ?ani: by a feminine noun, e.g. Pani: binit? 'which girl?'. An example of an adult Paj question is ?aj/Pani: Jugga ftare:t? 'which flat did you buy?' The answer often provides a description or further qualification of the noun, eg. likbi:ri 'the big one' or ?illi dzanb il-madrasi 'the one near the school'. This question construction emerged rather late in Juje's data.

(59) Juje (to grandma): Piza biddi:k tru: $\hbar i^{c} a$ ra:mi baru: $\hbar m a^{c} a: k i$. 'If you want to visit Rami, I'll go with you'.

Grandma: biddi. 'Yes, I want'.

Juje: ?aj sa: ${ }^{c} a$ ? [literally which hour?] 'What time?' [4;2,20]

Grandma: bukra l- ${ }^{c}$ asir 'Tomorrow afternoon'.

(60) Juje (watching a dog race on TV): ?anu: [kalb] Pilli fa:z? 'Which dog is the winner? [5;5,13] 
Mom: halla binfu:f. 'Now we'll know'.

\section{Ham's path of acquisition}

The analyzed data consisted of 2008 wh-questions which were collected from age $1 ; 2,26$ to $6 ; 0$. Below is a brief account of Ham's acquisition path of whquestions.

\section{The acquisition of mi:n 'who'}

Just like Juje, Ham's first wh-question was mi:n 'who' as a one-word question in subject position. It emerged at the age of 1;5,18 exactly in the same context it was produced by Juje, i.e. when he responded to a knock on the main door of their flat. However, it took Ham a few more months to produce mi:n in more complex constructions, particularly with the prepositions la 'to', $\mathrm{ma}^{\mathrm{c}}$ ' with' and min 'from'.

(61) Ham: we:n ra: $\hbar$ ba:ba? 'Where did dad go?'

Grandpa: ra: $\hbar$ Pidzi:b laban. 'He went to bring yogurt'.

Ham: la mi:n? 'To whom?' [2;1,2]

Grandpa: Pilak. 'To you'.

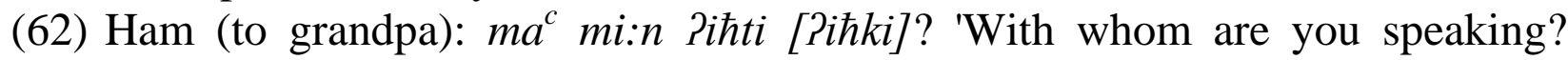
$[2 ; 5,15]$

Grandpa: $m a^{c}$ ?abu ?ija:d. 'With Abu Iyad'.

Ham: mi:n Pabu Pija:d? 'Who's Abu Iyad?'

Grandpa: $\underline{s a} \underline{b i}$. 'My friend'.

(63) Ham: ha:j hadijji. ?a?ullak min mi:n? 'This is a gift. Shall I tell you from whom I got it?; [4;1,29]

Grandpa: ?a: 'Yes'.

Ham: min Pil-miss. 'From the teacher'.

On examining Ham's mi:n questions, one finds that the overwhelming majority of the question words functioned as subject or part of a prepositional phrase; only an insignificant minority functioned as object/object complement as in:

(64) (Grandpa was in the bathroom and Ham's footsteps could be heard).

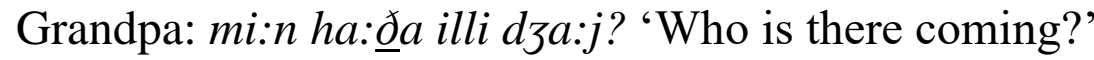

Ham: ћammu:di, mi:n fakkartni? 'Ham. Who did you think I was?' [4;3,26]

Grandpa: fakkartak Parnab. 'I thought you were a rabbit'.

The first prepositional question lami:n, 'whose', an independent question word was attested in Ham's speech shortly after he turned two.

(65) Ham: lami:n ha:j ['ilbit bo:dra]? 'Whose powder can is this?' [2;1,18]

Grandpa: ma bac rif. 'I don't know'. 


\section{The acquisition of we:n 'where'}

Ham was able to understand and respond to we:n 'where' questions when he was around a year and a half. Just like Juje, he demonstrated ability to identify his main body parts (e.g. ear, head, hand), belongings (e.g. shirt, toy, socks) and close family members (e.g. dad, mom, grandma) when asked to do so. It seems that this type of question-answer exercise is a common Jordanian and probably Arab conversational practice which, as it happened, showed up here.

(66) Grandpa: we:n dzu:d3? 'Where is Juje?'

Ham: o:n [ho:n]. 'Here]. we:n ba:aba? 'Where's dad?' [1;7,16]

Grandpa: fi-ffuвul. 'At work'.

A few months later, he was able to respond to and produce other we:n questions, including the use of we: $n$ in final position, when he was between 2;0 and $2 ; 6$ as in:

(67) Ham: we:n wayih [rayih $\underline{h}$ ? 'Where are you going?' $[2 ; 1,20]$

Grandpa: ?adzi:b sama:d. 'To bring a fertilizer'.

(68) Ham (to grandpa): Pinta tunt [kunt] we:n? 'Where were you?'

Grandpa: fil-hamma:m. 'In the bathroom'. [2;6,15]

Prepositional we:n questions which are structurally and cognitively more complex that their plain counterparts were attested in Ham's data when he turned three years and eight months.

(69) Ham: ha:j Pil-barra:jji min we:n faritu:ha? 'Where did you buy this sharpener from?' $[3 ; 8,1]$

Grandpa: $\min$ ? issu:g. 'From the market'.

Just like Juje, Ham used we:n in indirect questions.

(70) Ham: ?ana ba' rif we:n ra: $\boldsymbol{h}$ ba:ba. 'I know where dad went'. [3;6,13]

Grandpa: we:n? 'Where?'

Ham: ra: $\hbar$ jiftri sajja:ra. 'He went to buy a car'.

At a later stage, Ham sometimes used we:n questions to confirm a hypothesis rather than to seek new information about location. This was usually done through a follow-up yes/no question.

(71) Ham: we:n Pil-kanabaja:t? wadde:thum ' al be:t lidzdi:d? 'Where are the couches? Did you take them to the new flat?' $[4 ; 6,18]$

Grandpa: ?a:. 'Yes'. 
Probably as a sign of mastery of a certain wh-question is its use with other whquestions in the same exchange. Below are two examples of Ham's use of we:n followed by min ?aj 'which' and le: 'why'.

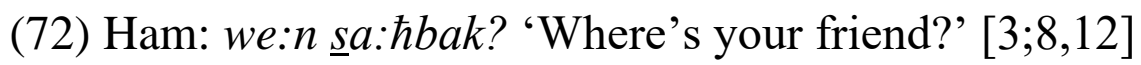

Grandpa: ra: $\hbar$. 'Left'.

Ham: $\min$ ? aj ba:b tili'? 'Which door did he leave from?'

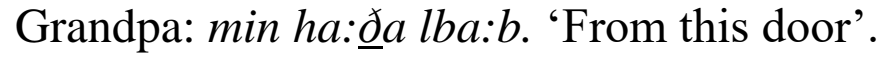

(73) [Ham came to his grandpa's study room in the evening and found him well dressed]

Ham: ta:lci:n we:n? 'Where are you going?' [4;1,19]

Grandpa: la? mif ta: $l^{c}$ i: $n$ ? No, we are not going anywhere?'

Ham: le: la:bis? 'Why are you well dressed?'

Grandpa: 'afa:n Patnaffat. 'To feel active'.

The acquisition of ?e: $\int / \int u$ : 'what'

The first $2 e: \int$ questions attested in the data asked about things/objects in the immediate environment whose lexemes were known to Ham. Around 1;9, he was able to answer ?e:f/fu: questions.

(74) Grandpa: ?e: Sha:j 'What's this?'

Ham: $\hbar a b b i\left[\hbar a b b i t^{c}\right.$ inab] 'A grape'. [1;9, 7]

The first $2 e:$ f question emerged toward the end of the second year.

(75) Ham (looking at wrapped boots): ?e: ha:d 'What's this?' [1;12,10]

Grandpa: bo:t 'Boots'

Ham continued to use $2 e: \int$ questions, particularly in game-like conversations which focused on naming and identifying body parts, e.g. eye, ear, head, face.

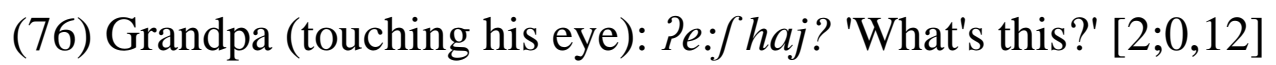

Ham: ?e:n [ $\left.{ }^{c} e: n\right]$. 'Eye'.

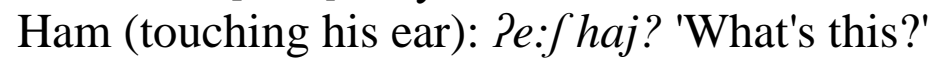

Grandpa: ða:n. 'Ear'.

Further, Ham used $f u$ : to seek answers to observations which he could not understand or explain.

(77) Ham (to his grandma who was not feeling well): fu: ma:lit [ma:lik]? 'What's wrong with you?' [2;3,23]

Grandma: $t a^{c} b a: n i$. 'Tired'.

Ham also used $f u$ : in indirect questions.

(78) Ham: si:di fi: namil ho:n. Paullak fu: lo:nu? 'Grandpa! There are ants here. Shall I tell you what colour they are?' (offer information) $[3 ; 7,17]$ 
Grandpa: ?a: 'Yes'

Ham: ?aswad. 'Black'.

Eventually, Ham also used the idiomatic expression fu: ra:jak 'what about' to make suggestions and exchange views on imaginary/sophisticated matters.

(79) Ham: si:du! fu: ra:jak $\underline{t i} \underline{c} \underline{t}$ :ni Pide:k $w$ a $a^{c} \underline{t}: k$ Pidajji? 'Grandpa! What about you give me your hands and I give you mine?' (make suggestions) $[2 ; 11,17]$

Grandpa: le:f. 'Why?'

Ham: li?annu Pide:k bardi:n. 'Because your hands are cold'.

(80) [Fake telephone conversation withYousef, an imaginary friend]

Ham: fu: ra:jak Pinћut xutta nsa:fir cala ?amri:ka? 'What about having a plan to visit America?'

[He didn't invent an answer but went on and on]

tidzdzawwaz? Ju: Pisim maratak? liana? walla zaj Pisim ma:ma. 'Do you want to get married? What's the name of your wife? Liana? Just like my mom's name'. $[5 ; 1,18]$

However, the main purpose of e: $\int$ questions was to seek information on events or phenomena whether in the immediate environment or not.

(81) Ham (to grandpa): ?e: țabaxtu? 'What did you cook?' [3;3,28]

Grandpa: bando:ra, wintu? 'Tomato and you?'

Ham: ninda:n [ba:ðindza:n]. 'Eggplant'.

(82) Hammoud (talking about a school trip): ?a?ullak fu: aktar licbi ?acdzbatni? 'Shall I tell you what game I liked most?' $[5 ; 7,0]$

Grandpa: ?a: 'Yes'.

Ham: ble: ste:/in. 'Play Station'

The acquisition of le: ' 'why'

The first adjunct le: 'why' question was attested in Ham's data at the age of $2 ; 5,15$ when he saw his grandpa flipping through some sheets.

(83) [Grandpa flipping through some sheets]

Ham: biddi. 'I want (a sheet)'.

Grandpa: dafJirhin 'Leave them'.

Ham: le:f? 'Why?' [2;5,15]

Grandpa: haðo:l la-ldza:mc $m^{c}$. 'These are university sheets'.

Ham was aware that le: asks about reason. Further, he knew that in his dialect one can also ask about reason using ma:l [or fu: ma:l], a lexical synonym of le:f, as in: 
(84) [Grandpa was laughing]

Ham (commented): ma:l si:du bid $\hbar a k k$ ? 'Why is grandpa laughing?' [2;6,7]

As is clear, Ham was a sharp observer of the conversation context. When he did not understand the reason underlying a certain phenomenon, he promptly asked about it.

(85) [Uncle Wael stepped in. He frowned at Ham and made loud and strange sounds]

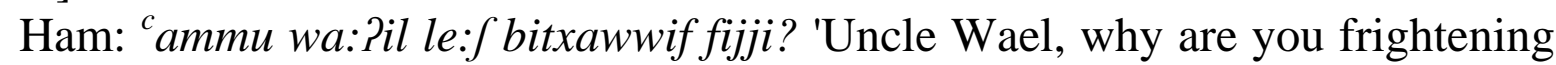
me?' $[3 ; 3,10]$

Uncle: ?ana $b a l^{c} a b m a^{c} a k$. 'I am playing with you'.

His late le: questions showed Ham's more direct involvement in discussions and events, voicing his views, particularly when disagreeing, as in.

(86) [The maid was offering coffee to guests and family members. Some didn't take coffee and a discussion started on whether coffee was a healthy drink or not]

Ham: le:厅 si:idi bithib Pil?ahwi? 'Grandpa! Why do you like coffee?' [4;3,11]

Grandpa: la?inha za:kji. 'Because it's delicious'.

Ham: la? ћa:mda. 'No, it's sour'.

When Ham turned five and went to kindergarten, he learnt lima:ða, the standard Arabic variant of $l e: \int$ and started using it.

(87) [Juje appeared with a mask and started playing monkey]

Ham: lima:ða: Pinta he:k? 'Why are you wearing a mask?' [5;1]

Juje: munki munki jac ni Pird. 'Munki munki. This means monkey'.

Ham also used $l e: \int$ for purposes other than requesting an explanation or asking for a reason. Below is an example of using le:f to tease his grandpa, another manifestation of cognitive development.

(88) [After the sunset]

Ham: saba: $\hbar$ Pilxe:r. 'Good morning'.

Grandpa: la: masa lxe:r. 'No, good evening'.

Ham: le:f? hijji Piddinja lmasa? 'Why? Is it evening?' [5;10]

Grandpa: ?a: 'Yes'.

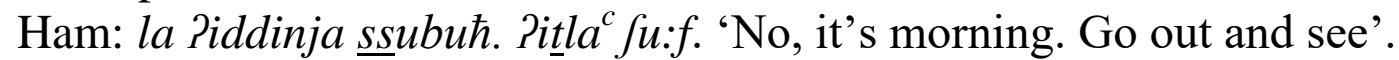

Grandpa: btitxawwath ja hammu:di? 'Are you fooling me Ham?'

Ham: la? badza:kir. 'No, I am teasing you'.

Just like Juje, Ham used le: $\int$ in embedded clauses in indirect questions with a view to providing information that was not sought by his interlocutor.

(89) Ham: bti ${ }^{c}$ rif le:S Pana basa: ${ }^{c} d a k$ ? 'Do you know why I help you?' [5;6,19] 
Grandpa: la?. 'No'.

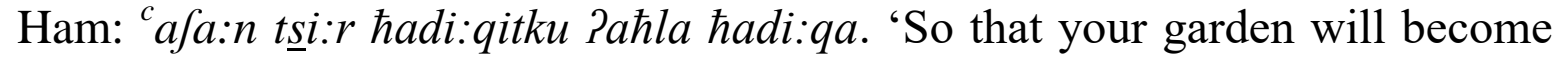
the most beautiful'.

Grandpa: Jukran. 'Thanks'.

The acquisition of ke: $f$ 'how'

Just like Juje, Ham showed a relatively early understanding of the ritualized and routine question ke:f ha:lak 'how are you' and was able to respond to it verbally when he was two years old.

(90) Grandpa: ke:f ha:lak? 'How are you?'

Ham: ћamdulla. 'Thanks to Allah'. [2;0]

The first ke:f construction Ham produced was in an embedded nominal clause when he was around three, trying to reach a toy on a shelf.

(91) Ham (to grandpa): ?ittalla ke:f Patu:l haj. Pana tawi:l. 'Look how I can reach this. I am tall'. [2;11,18]

Grandpa: mazbu:t. 'Right'.

Shortly after that, he displayed sufficient awareness that ke:f is a manner adverbial when he used it to convey different pragmatic functions including to request clarification, check on someone, or ask about the weather, etc.

(92) Grandpa: biddi Paћuttilak fawa:rib. 'I want to make a moustache for you?' $[3 ; 1,22]$

Ham: ke:f biddak ћuttili fawa:rib? 'How can you make a moustache for me?' (Request for clarification)

Grandpa: bagus min fawa:rbi $w$ baћut ${ }^{c} a l e: k$. 'I cut from my moustache and put on yours'.

(93) Ham: ke:f Pilhimmi? 'How is your morale?' [4;6,5] (asking about one's psyche)

Grandpa: 'a:lji. 'Great'.

(94) Ham: ke:f Pildzaw? 'What's the weather like?' [4;11,28] (Asking about the weather)

Grandpa: da:fi. 'Warm'.

Ham also used ke:f in fake dialogues (of his own creation) with his grandma.

(95) [Fake telephone conversation with his grandma]

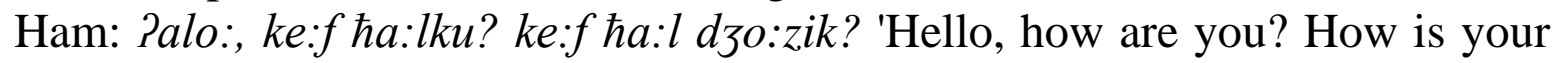
husband?' [3;6,26]

Grandma: kwajjis. Jukran. He is doing well. Thanks'. 
Ham also used ke:f as a direct object clause to express manner and provide subsequent feedback.

(96) Ham: btic rif ke:f tsawwi tajjara? 'Do you know how to make a plane?' [5;2,7] Grandpa: la?. 'No'.

Ham: ?ana ba' rif. 'I know'. [He drew a plane]

The acquisition of gadde: //kam 'how many/how much'

When Ham was exposed to a gadde: $\int$ question, he answered, unlike Juje, using a specific number followed by the word kti:r 'a lot'.

(97) Grandpa: bithibni ja hammu:di? 'Do you love me Ham?' [2;11]

Ham: ?a:. 'Yes'.

Grandpa: gadde:/? 'How much?'

Ham: ?tne:n. kti:r 'Two, a lot'.

It seems that he was not sure that gadde: $\int$ does not require a specific number when it collocates with 'love' and thus he continued with a neutral term (kti:r) that can be used for both quantity and quality.

Analysis of Ham's data suggests that gadde: $\int$ is acquired rather late, not before turning four. Below is his first kam/gadde: $\int$ question which required a quantitative answer.

(98) [Ham had a haircut]

Grandpa: $n a^{c} i: m a n$ ja ћammu:di. 'Avery nice haircut, Ham'.

Ham: Palla jin' im 'ale:k. 'God may bless you'.

Grandpa: na i:man ja ћammu:di. 'Avery nice haircut, Ham'.

Ham: kam marra ?ultilli? 'How many times have you told me?' [4;3]

The acquisition of wakte:fl?e:mta 'when'

Although Ham was able to show understanding of the concept of time when he was around two years old, his first Pe:mta 'when' question was attested after four.

(99) Grandpa: Pana biddi Pathammam. 'I want to have a bath'.

Ham: Pe:mta biddak tithammam? 'When do you want to have a bath?' [4;5]

Grandpa: bas jidfa lhammam. 'When the bathroom becomes warm'.

Ham's late productions of ?e:mta occurred in longer and more complex constructions.

(100) Ham: ba:ba, Pe:mta bidna nru: $\hbar^{c}$ a da:r xa:ltu dja:la? 'Dad! When do we want to go to Aunt Diala's house?' $[5 ; 10,26]$

Dad: mif'a:rif. 'I don't know'.

\subsection{The acquisition of Paj/Panu: 'which'}

The first ?aj question emerged rather late in Ham's data.

(101) Mom: dzi:b Pil-mukinsi. 'Bring the vacuum cleaner'.

Ham: fi ?aj Burfi? 'In which room?' [3;2,16]

Mom: xalas bala:.. 'Not needed any more'. 
$? a j+$ Noun is sometimes equivalent to $? e: m t a$ 'when/what time' as in:

(102) [Ham found that his favourite TV series episode is over]

Ham: ha: da lmusalsal mxallis. ?aj sa: ${ }^{c} a$ bibda. 'This episode is over. What time does it start?' [4;2]

\subsection{Comparison between the two paths}

Before we proceed, it is useful to observe that the age of first use is sometimes suggested as the acquisition criterion. In this context, Stromswold (1995, p. 28) considers the age of first use as "the most sensitive measure of acquisition because it measures the earliest age at which a child could be said to have acquired a construction." However, we think that acquisition is a long and complex process and thus the age of first use is better viewed as the emergence point of acquisition. To minimize the possibility that the first use is not a natural and spontaneous utterance, i.e. a speech error or a formulaic question or an imitation, the context of each occurrence was carefully checked. To answer the first study question on which wh-questions the subjects found easier and thus acquired earlier and the reasons underlying this sequence, one first needs to identify the first natural and spontaneous use of each question word and construction. Once this sequence is known, an interpretation will be provided. Below is a chronological order of the age of first use (emergence) of each wh-question by Juje and Ham.

Table 1

Chronological order of the age of first use (emergence) of each wh-question by Ju:ju and Ham*

\begin{tabular}{|c|c|c|}
\hline Wh-question & Juje (Y, M, D) & $\operatorname{Ham}(\mathbf{Y}, \mathbf{M}, \mathbf{D})$ \\
\hline mi:n ‘who’ & $1 ; 8,2(1)$ & $1 ; 5,18(1)$ \\
\hline we:n 'where' & $1 ; 10(2)$ & $1 ; 7,16(2)$ \\
\hline 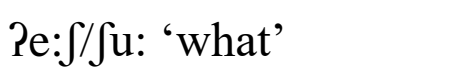 & $2 ; 2(3)$ & $1 ; 12,10(3)$ \\
\hline le:f ‘why’ & $2 ; 4,10(4)$ & $2 ; 5,15(5)$ \\
\hline lami:n 'whose' & $2 ; 4,25(5)$ & $2 ; 1,18$ (4) \\
\hline ke:f 'how' & $2 ; 9,22(6)$ & $2 ; 11,18(6)$ \\
\hline $\begin{array}{l}\text { gadde: } / \text { kam 'how } \\
\text { many/much' }\end{array}$ & $3 ; 8,26(7)$ & $4 ; 3(8)$ \\
\hline wakte:f/?e:mta 'when' & $4 ; 6(9)$ & $4 ; 5(9)$ \\
\hline Pay/Ranu: 'which' & $4 ; 2,20(8)$ & $4 ; 2(7)$ \\
\hline
\end{tabular}

Note. *Rank order of each wh-question appears in brackets next to the age of first use.

The table shows that while mi:n 'who' was the first wh-question both Juje and Ham produced, wakte:f/Re:mta 'when' was the last. The former was acquired around age one year and a half and the latter around four years and a half. The other questions appeared in almost the same sequence with the exception of gadde: $\int / \mathrm{kam}$ 'how many/much' which ranked seven for Juje and eight for Ham and Paj/Panu: 
'which' that ranked eight for Juje and seven for Ham. These findings are not always in line with the data given by Marwan and Dima in Abdo and Abdo (1991). While Marwan acquired we:n 'where' first followed by ?e:f/fu: 'what', Dima acquired both mi:n 'who' and we:n first and at the same age. However, the two studies showed more harmony with regard to those wh-questions that were acquired last or toward the end of the acquisition path, viz., ?e:mta 'when' and ?aj 'which'. These differences might be a reflection of parental input, frequency of occurrence and acquistional context. Marwan and Dima were brought up by Palestinian highly educated parents while they were working and residing as a nuclear family in Kuwait. In contrast, Juje and Ham were part of a large extended Jordanian family in Amman with frequent visitors knocking at the door or ringing the intercom bell who were requested to disclose their identity by responding to a mi:n question.

The early emergence of mi:n, we:n and $2 e: \int / \int u$ : questions is in line with the nature of children's early and urgent communicative needs which include, among other things, learning the names of objects, people and places around them to make their lives easier and more meaningful. This is enforced by their care givers' frequent use of these questions in the context of introducing names of objects, people and places or asking children to identify or verify them.

Apparently, the sequence of acquisition of wh-questions as revealed in the data supports a cognitive maturity interpretation regardless of language and culture. The acquisition of wh-questions that ask about concrete objects/entities, i.e. mi:n 'who', we:n 'where' and Pe:f/fu: 'what' were emerged earlier than those questions which ask about abstract objects/entities, i.e. le:f 'why', ke:f 'how', gadde: $/$ kam 'how many/much' and wakte:f/Re:mta 'when'. However, the questions within each of the two sets were not equally easy/difficult. In the first category, mi:n ranked first on the easy/difficult scale while $? e: \int / \int u$ : ranked third. The order of acquisition in the second category suggests that it was easier to ask about reason (le:f) than about time (wakte://Pe:mta) and that to ask about quantity and quality (gadde: $/ \mathrm{kam}$ ) was more difficult than to ask about manner (ke:f).

Cairns \& Hsu (1978) ascribed the variable difficulty of 'why' and 'when' questions in English-speaking children to progression in the children's ability to encode the concepts of causality and time linguistically. This interpretation is supported by Juje's and Ham's late acquisition of wakte:f/Re:mta 'when' and le: 'why' though to a lesser extent. It seems that children also encounter serious difficulty on their way to encode the concepts of quantity/numbering and quality scale. Further, Cairns \& Hsu (1978) reported similar difficulty with how questions because they "involve a number of unrelated skills" (p. 477). In effect both Juje and Ham found ke:f 'how', the manner interrogative adverbial, relatively difficult as manner involves change of state and sharp observation of this change.

The cognitive maturity interpretation approach suggested by this study received support by the generally similar path of acquisition found in Englishspeaking children regardless of the different morphophonemic structure of whquestion words in Arabic and English, the two genetically unrelated languages. 
While question words in English start with a round bilabial glide /w/ or a voiceless glottal fricative $/ \mathrm{h} /$ and consist of one syllable, and thus do not display variable linguistic difficulty, question words in JSA do not share the same initial sound nor do they consist of the same number of syllables. In this context, one may wish to

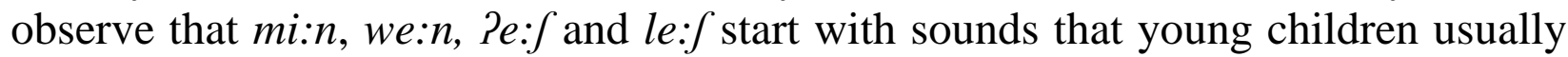
find easy to produce in addition to the fact that these words are monosyllabic. In contrast, the (rather) late acquired words ke:f, gadde: $\int$ and wakte://Re:mta either start with velar sounds which Jordanian Arabic-speaking children tend to acquire rather late and/or consist of more than one syllable. Apparently, this morphophonemic difference has not significantly impacted the sequence of acquisition of these questions in the two languages. However, the late acquisition of $/ \mathrm{k} /$ and $/ \mathrm{g} /$ in JSA might have also contributed, together with their multiple syllable structure, to the late acquisition of ke:f, gadde: and Pe:mta.

An earlier study on the acquisition of wh-questions by English-speaking children highlighted that such a sequence was also a feature of their path of acquisition.

In light of the foregoing, one can claim that there seems to be a universal acquisition path of wh-questions regardless of language background and languagespecific complexity.

\section{Symptoms of complete acquisition of wh-questions}

Careful analysis of the dynamic and detailed progress of wh-questions in the two children from the first use (emergence) of each question until the onset of schooling suggested that the following symptoms characterize the final or nearfinal stage of JSA children's acquisition of wh-questions.

1. Use of the wh-question complex and long constructions, e.g. object in indirect questions

The use of wh-questions in a complex sentence where the wh-word prefaces a clause with a grammatical function (object) is seen as an indicator of the child's ability to control the target question compared with initial use of it as a one-word question or a question in a short simple one clause sentence. Below are two examples are extracted from the data presented earlier and repeated below for the reader's convenience.

(103) Juje: bas ?akbar limcalmi bit'allimni ke:f Paktub. 'When I grow up the teacher will teach me how to write'. [3;4,26] (51 above)

(104) Ham: ?ana bacrif we:n ra:h ba:ba. 'I know where dad went'. [3;6,13]) (70 above)

2. Use of the standard Arabic (SA) variant and the dialectal variant as alternates

The ability to alternate between the standard and vernacular forms before schooling where the official exposure to standard Arabic starts is seen as a sign of language maturity.

(105) (Juje using SA Pajna 'when' for JSA we:n)

Juje: Pajna ?anta muxtafi ja: si:du 'Where are you hiding, grandpa?' [4;10] (26 above) 
(106) (Ham using SA lima:ða 'why' and for JSA le:f wondering why Juje was wearing a mask playing a monkey)

Ham: lima:ða: Pinta he:k? 'Why are you wearing a mask?' [5;1] (87 above)

It seems that the use of Standard Arabic here is influenced by the children's exposure to dubbed TV cartoons.

3. Use of the target wh-question with other questions in the same exchange

Juje used wh- and yes/no questions as in:

(107) Juje: Pinta ${ }^{c}$ indak baru:di 'Do you have a gun?' [3;8,13] (24 above)

Grandpa: ?a: 'Yes'

Juje: we:nha 'Where is it?'

Grandpa: biddi:: ?agullak 'I don't want to tell you'.

Ham used we: $n$ 'where' followed by min ?aj 'which' as in:

(108) Ham: we:n sa: $\hbar b a k$ ? 'Where's your friend?' [3;8,12] (72 above)

Grandpa: ra: $\hbar$. 'Left'.

Ham: min ?aj ba:b tilil ? 'Which door did he leave from?'

4. Use of the target wh-question to convey different pragmatic functions

It is believed that the child's ability to use the target wh-question to convey pragmatic functions other than seeking mere information is a sign of remarkable advancement along the acquisition path. This was evident in Juje's 31-34 tokens above in which he showed unease with a bad smell (109 below), requested clarification, protested and made a comment.

(109) Juje (showing unease with a bad smell): fu: ri:ћa? 'What's this bad smell?' $[2 ; 8,4]$

Grandpa: sama:d. 'Fertilizer'.

Likewise, Ham used using ke:f in tokens 92-94 to ask for clarification, one's check on someone (110 below) and ask about the weather, among others.

(110) Ham: ke:f Pilhimmi? 'How is your morale?' [4;6,5]

Grandpa: 'a:lji. 'Great'

5. Use of the target wh-question as part of an idiomatic expression

Idiomatic use of language is often viewed as a sign of acquisition. In this context, both Juje and Ham used the JSA expressionas Ju: ra:jak 'what about?' (36 and 79 above).

6. Use of the target wh-question in fake or imaginary dialogues

The child's ability to include a wh-question in an imaginary dialogue of his own creation in which he assumes two roles (he and another person) is a sign significant progress along the acquisition bath. This was evident is Juje's and Ham's fake dialogues illustrated in 35, 49,50, 80 and 95 above, among others.

7. Use of wh-word synonyms

Both Juje and Ham were able to use $2 e: \int$ and $\int u$ :, the equivalents of 'what' as synonyms. This was illustrated in 29 vs. 31 (Juje) and 76 vs. 77 (Ham).

8. The use of the same wh-question in different structural constructions 
The ability to use the same question word in different structural constructions (e.g. (verbless, intransitive, transitive, prepositional phrase) is viewed as a sign of acquisition.

Juje's use of mi:n 'who' in 12 (verbless), 14 (intransitive) and 17 (transitive) above is self-evident.

Ham also used the prepositional construction min we:n 'from where' in 69 above and repeated below for convenience:.

(111) Ham: ha:j Pil-barra:jji min we:n faritu:ha? 'Where did you buy this sharpener from?' $[3 ; 8,1]$

Grandpa: min ?issu:g. 'From the market'

To conclude, these features need to be further examined on the basis of crosslinguistic data to decide whether they are language specific or show a tendency toward universality.

\section{Conclusions and Recommendations}

The longitudinal study reported here was solely devoted to offering a description of wh-questions in Jordanian Spoken Arabic in addition to investigating how these questions were acquired by Jordanian-Arabic speaking children residing in Amman, Jordan. It argued for a cognitive maturity approach to interpret the sequence of acquisition suggested by the data regardless of language and culture. The acquisition of wh-questions that ask about concrete objects/entities, i.e. mi:n 'who', we:n 'where' and Pe:f/fu: 'what' were produced and developed earlier than those questions which ask about abstract objects/entities, i.e. le: 'why', ke:f 'how', gadde://kam 'how many/much' and wakte://Re:mta 'when'. However, the subjects did not find the questions within each of the two sets equally easy/difficult. In the first category, mi:n ranked first on the easy/difficult scale while ?e:f/fu: ranked third. The order of acquisition in the second category suggested that it is easier to ask about reason (le:f-why) than about time (wakte:f-when) and that to ask about quantity (gadde: $\int / \mathrm{kam}$-how many/much) is more difficult than to ask about manner (ke:f-how). The study also identified a set of features which may be used to judge how close the child is to native-like competence. The more features are available, the closer the child is to complete or almost complete acquisition of wh-questions.

Future research may examine the acquisition of these questions by speakers of other spoken varieties of Arabic. It may also focus on the acquisition of yes/no questions in JSA and beyond.

\section{References}

Abdo, D., \& Abdo, S. (1991). Fi: Lughat At-tifl, Al-Juz' 1, Al-Mufradat [In child language, part 1, vocabulary]. Amman: Al-Karmel Publishing House.

Abulhaija, L. (1989). The development of negative structures in children: Evidence from Jordanian children. Arab Journal for the Humanities, 9(36), 343-372.

Amayreh, M., \& Dyson A. (1998). The acquisition of Arabic consonants. Journal of Speech and Hearing Research, 41(3), 642-653. 
Al-Momani, I., \& Al-Saidat, E. (2010). The syntax of wh-movement in Jordanian Arabic. European Journal of Scientific Research, 40(4), 609-628. Retrieved from: http://www.eurojournals.com/ejsr.htm

Bloom, L., Markin, S., \& Wooten, J. (1982). Wh-questions: linguistic factors that contribute to the sequence of acquisition. Child Development, 53(4), 1084-1092.

Cairns, H., \& Hsu, J. (1978). Who, why, when and how: a developmental study. Journal of Child Language, 5(3), 477-488.

Ervin-Tripp, S. M. (1970). Discourse agreement: How children answer questions. In J. R. Hayes (ed.) Cognition and the development of language (79-107). Wiley: New York.

Ghodayyah, I. (2019). The acquisition of noun plurals in Jordanian Arabic. (Unpublished MA thesis). the University of Jordan, Amman, Jordan.

Hamdan, J. \& Amayreh, M. (2007). Consonant profile of Arabic-speaking school-age children in Jordan. Folia Phoniatica et Logopaedica, 59, 5-64. https://doi.org/10.1159/000098338

Kalaldeh, R. (2018). Acoustic analysis of Modern Standard Arabic vowels by Jordanian speakers. International Journal of Arabic-English Studies, 18, 23-48.

Li, H., Tse, S., Wong, J., Wong, E., \& Leung, S. (2013). The development of interrogative forms and functions in early childhood Cantonese. First Language, 33(2), 168-181. https://doi.org/10.1177\%2F0142723713479422

Radford, A. (1990). Syntactic theory and the acquisition of English syntax. Cambridge, Massachusetts: Basil Blackwell.

Ravid, D., \& Farah, R. (1999). Learning about early noun plurals in Palestinian Arabic. First Language, 19(56), 182-206. https://doi.org/10.1177\%2F014272379901905603

Stromswold, K. (1995). The acquisition of subject and object wh-questions. Language Acquisition, 4(1/2), 5-18. https://doi.org/10.1080/10489223.1995.9671658 